\title{
Economic Interests of Media in the Coverage of the News Value of Sex on the Harian Rakyat Aceh
}

\author{
http://dx.doi.org/10.25008/jkiski.v5i2.413
}

\author{
Hamdani M. Syam ${ }^{1 *}$, Nur Anisah ${ }^{2}$, Rahmat Saleh ${ }^{3}$, Abdul Rani Usman ${ }^{4}$, Dini \\ Khairani $^{5}$ \\ 1,2,3,5 Department of Communications, Universitas Syiah Kuala \\ Jl. T. Nyak Arief Darussalam, Banda Aceh 23111 - Indonesia \\ ${ }^{4}$ Department of Communication and Islamic Broadcasting, Universitas Islam Negeri Ar-Raniry \\ Jl. Syeikh Abdul Rauf, Kopelma Darussalam, Banda Aceh 23111 - Indonesia \\ ${ }^{*}$ Corresponding author: hamdanim.syam@unsyiah.ac.id
}

Submitted: September 09, 2020, Revised: November 28, 2020, Accepted: December 15, 2020

Accredited by Kemristekdikti No. 28/E/KPT/2019

\begin{abstract}
In addition to having the freedom to spread news to the public, the press also have the freedom to search and process news. In exercising that freedom, journalists always consider that news must be interesting so that people want to read it. The media coverage of sex, including stories on rape, sexual harassment, adultery, cheating, and sordid topics, is a news value that has a high rating for people. Sometimes in the economic interests of the media, journalists violate the norms and ethics of the news. This study is aimed to examine through content analysis the coverage of sex in the Harian Rakyat Aceh newspaper, which from January to April 26 featured 54 articles related to sex. This study examined this coverage in the context of Indonesia's implementation of the journalistic code of ethics. Indonesian journalists are prohibited from mixing facts and opinions and from reporting sadistic and obscene news. Using the Holsti formula, inter-coder reliability resulted in a CR of 0.99 , showing strong reliability. After data collection, coding sheets were analyzed using SPSS software to determine the results of each category. This study found that the news value of the 54 articles in the Harian Rakyat Aceh newspaper is considered to have violated the journalistic code of ethics. Thus, it can be assumed that there is an economic interest in the media's reporting of sex in that newspaper.

Keywords: Media economics, news value of sex, Harian Rakyat Aceh, freedom to spread news, content analysis the coverage of sex
\end{abstract}

\section{Introduction}

Since the reform movement began in 1998, the mass media in Indonesia has changed from being state-controlled to market-oriented. Consequently, the mass media no longer face intervention by the state in delivering news. Instead, news is determined by the market. The media are no longer a social and political institution but an economic one (Arifin, 2017; Malik, 2018; Setiowati, 2010; Susilastuti, 2000). Economics is one factor that can influence the mass media (Fengler \& Rub-Mohl, 2008; McManus, 1995; Reese, 2001; Russ-Mohl, 2006). In reporting news, media owners or journalists no longer reckon the extent to which written news is beneficial to the public. More often they are influenced by the market, so journalists very rarely think about the quality aspects of news for the public.

The market-driven nature of the media has long been discussed by Dimmick and Rothenbuhler (1984). Mosco (1996) said that the mass media are very difficult to move related to their ideals regarding the news. Most news is motivated by certain interests, especially economic ones. The mass media are a human tool for understanding social reality, so they are regarded as neutral. But the media are loaded with 
various interests, mainly economic (Allern, 2002; Reese, 2001; Russ-Mohl, 2006; Shoemaker \& Reese, 1996). The media are often accused of bias in selecting and processing information to be reported.

The economic interests of the media are also driven by competition between outlets. The media that have many readers will certainly get a stronger economic source than the media that have less readers. Journalists, as they gather and write the news, often consider the extent to which the news will be read by the public (AttawayFink, 2005; Cohen, 2002; Curtin, 1999; McManus, 1995; Picard, 2010). The news is the same but presented differently by the various media outlets. Journalists often compete to pack news to appeal to the public to read it.

In the era of media competition, the news value of sex is considered a value that can bring economic benefits; sex is news (Baum, 2002; Greer, 2010; Harcup \& O'Neill, 2001; Van Zoonen, 1988) and is always associated with women. Throughout the history of human civilization, everything related to women must be interesting to read, contain a high news value, and become an appeal for the mass media to publish because sex is considered to have an economically promising news value.

In the context of sexual violence concerning women, the media tend to cover rape and sexual violence in a sensational and dramatic manner (Barton, 2017; Bufkin \& Eschholz, 2000; Carter, 1998; Greer, 2010; Kitzinger, 2004). When journalists cover events such as rape, sexual harassment, adultery, cheating, and sordid topics, they often compete to write about them as interestingly as possible (Ward, 2005; Wilkins \& Brennen, 2004; Wulfemeyer, 1985). Researchers have found that most journalists, in writing stories about rape and sexual violence, often ignore the journalistic code of ethics (Iggers, 2018; Ryan, 2001; Wilkins \& Brennen, 2004; Wulfemeyer, 1985).

In Indonesia, the journalistic code of ethics stipulated by the Press Council in 2008 regulates such reporting. According to this code of ethics, Indonesian journalists are banned from mixing facts and opinions, and creating sadistic and obscene news stories. However, this is often ignored by media owners on account of the importance of media economics. The depiction of pornography in the news is often seen as a means to inform audiences and as a form of prevention for the community (Bufkin \& Eschholz, 2000; Harcup \& O'Neill, 2001; Harris \& Scott, 2002; Otto, 1963). But, on the other hand, news that tends to be vulgar can be a means of socialization for the community. Reports of rape, adultery, sexual harassment, cheating, and sordid topics, without filtering and framing, potentially teach audiences to commit the same crime.

Based on these issues, this research examined the coverage of sex-related news in the Harian Rakyat Aceh newspaper in Indonesia. These stories are defined for this study as news related to rape, adultery, sexual harassment, cheating, and sordid topics.

This study selected the Harian Rakyat Aceh newspaper, considering that it is published and circulated in Aceh. The people of Aceh are the main target audience. The most powerful news value is proximity so news that has elements of closeness with the people of Aceh is considered important. Proximity is news relating to the people, events, organizations, and institutions that occurs in a place close to the publishing company (DeLung, Magee, DeLauder, \& Maiorescu, 2012; Harcup \& O'Neill, 2001, 2017; Shoemaker et al. 2007). Readers want to know something about their environment and society. They want to know about neighbors, friends, and relatives published in the news. Editors believe that readers are more interested in events that occur in their own society than in events that occur elsewhere.

The Harian Rakyat Aceh newspaper was also chosen because it was established on January 17,2005 and is the second daily newspaper in Aceh after the Serambi Indonesia. The two papers must compete to get readers. This affects the form of news coverage in the Harian Rakyat Aceh newspaper itself.

Media ratings also have an effect on media coverage (Allern, 2002; Attaway-Fink, 2005; Lee, 2009; Jenkins, 2004). Media compete to get readers for the sake of their economy, so news stories concerning sex topics are presented to readers almost every day by the Harian Rakyat Aceh newspaper. The daily papers of Aceh do this because of a specific purpose associated with such news, perhaps including their economic interests and competition for readers.

The Harian Rakyat Aceh newspaper is operated under the auspices of the Jawa Post News Network, the largest newspaper network company in the capital city of Jakarta. The Harian Rakyat Aceh prints 15,000 copies per day. Local news comprises an estimated $75 \%$ of its 20 pages, with the rest being national and global news.

This study was designed to answer the following research questions: (1) How much of the news is related to incidents of rape, adultery, sexual harassment, cheating, and sordid topics in the Harian Rakyat Aceh newspaper?; (2) Is there proximity with the people of Aceh in the coverage 
of news related to incidents of rape, adultery, sexual harassment, cheating, and sordid topics in the Harian Rakyat Aceh newspaper?: (3) Do the journalists of the Harian Rakyat Aceh newspaper mix facts and opinions or present sadistic and obscene coverage of news related to incidents of rape, adultery, sexual harassment, cheating, and sordid topics?

\section{Theoretical Framework}

Many scholars have defined news as a report that contains information, something new, or something that is happening (Allern, 2002; Elliott, 1988; Fuller, 1996; O’Neill \& Harcup, 2009; Singer, 2010). News also can be said to be a report of ideas, events, or conflicts that attracts the attention of and has meaning for the audience (Brighton \& Foy, 2007). News can be delivered in print, broadcast, on the internet, or by word of mouth.

According to Lee (2009), news has become a necessity for the wider community. But not all information about something happening in this world deserves to be raised into a news story. There are certain values that must be met for the event to be considered news and important enough to be reported through the mass media.

News also can be defined as something that happens that attracts the attention of many people. Information about the birth of a neighbor's child may be important news for people who are close to the child, but it is not important news for the media because not many people will be interested in reading about it unless there is something unique in the child's birth.

Something can be said to be news if it contains news values (O’Neill \& Harcup, 2009). Journalists almost every day and do not know the time to look for events in the people and judging them to be worthy of news or not. According to Campbell (2001), every newspaper has different news values. Some scholars of journalism (Allern, 2002; Baum, 2002; Blood \& Phillips, 1997; Brighton, \& Foy, 2007; Greer, 2010; Harcup \& O'Neill, 2017; O'Neill \& Harcup, 2009; Ryan \& Tankard, 1977; Shoemaker et al., 2007; Sultana \& Harikrishnan, 2014) have said news is considered valuable if it contains some of the following criteria:

Proximity - the main and most important news value. Shoemaker et al. (2007) said the media will always prioritize events that occur in a place close to the reader.

Prominence - news involving famous personalities including well-known institutions. Prominence also means news coming from important people in government or public figures or important institutions in society (e.g., the Presidential Palace is on fire).

Timeliness - actual or recent events. What happened yesterday is old news because people already know about it from other sources.

Influence (impact) - the effect of news on the audience. The size of the impact of an event determines its value as news; the more people affected, the wider the impact, and the longer the impact increases a story's news value.

Magnitude - the number of people involved. The scale of the story is very important in terms of influence. Like influence, magnitude is measured by such things as the involvement of many people, large-scale environmental damage, high achievement, and large profits and losses. The bigger the involvement, the more important the news.

Conflict - a contradiction either through deeds or minds among individuals, organizations, or countries. Ryan and Tankard (1977) said conflict is an ever-prevalent social reality and includes disagreements, debates in politics, and demonstrations that lead to violence.

Oddity - an unusual event in society. According to Brighton and Foy (2007), something new to the reader or something which rarely happens is news that catches the public's attention. When a story that otherwise would be considered big news happens every day and is read in the same form, then it is not interesting news. For example, interesting news would be "Man bites dog" but not "Dog bites man." The news oddity is something that contains elements of human interest which invites the public to read the news.

Sex -incidents of rape, sexual harassment, adultery, cheating, and other sordid topics. For example, news of an actor suing his wife for divorce after she, also an artist, has an affair with the chairman of one of the political parties. Sex news always involves both women and men. According to Baum (2002), Greer (2010), and Sultana and Harikrishnan (2014), stories about sex have a high news value.

\section{Media Economic}

Behind the news of events, the media hold certain interests, one of which is its economic interests. Most news is motivated by certain interests (Allern, 2002; Beam, 2003; Cohen, 2002; Curtin, 1999; McManus, 1995). The quality of the produced news can be determined largely by the economic interests of the media owners and policymakers.

The media economy views the media as an industry or institution that can be used for profit. 
Shoemaker and Reese (1996) stated that the news production process will be done by those in power to determine what news is worth producing or discarding and how the news will be reported. Media owners and editorial teams direct and monitor what will be published and how it is written. They calculate if the public will like the news. Thus, the quality of news highly dependent on the policy of the media institution. So, the media should be tasked to deliver the news as it is, not turned into the hidden interests of the media institution. For example, one event is sometimes reported with different viewpoints by different media. One media outlet may accentuate side A, but other media outlets may highlight side B.

The media, in principle, will always be driven by the market (Beam, 2003; Cohen, 2002: Curtin, 1999). Here one can see which actors are more dominant in determining media content; it can be news sources, owners, advertisers, and consumers (Allern, 2002; Reese, 2001; Shoemaker \& Reese, 1996). The mass media will innovate to adapt the forms to the needs and desires of the people. There are three sources of life for the media: content, capital, and audience (Dimmick \& Rothenbuhler, 1984). Content is related to what is published in the media. Capital is the source of funds that support the media, which can be a media owner as well as an advertiser. Audience is the public or readers.

The media economy is always associated with these three factors and their interconnectedness. The quality of news produced by the media can be largely determined by the economic interests of media owners and policymakers. The simple assumption is that the content of the news is regulated more by the economic powers of the media. Why should this be so? Why do the media only facilitate certain individuals or groups? Why do the media present a particular point of view or issue? All that has something to do with the interests of the media (Cohen, 2002).

It is possible for advertisers and media owners to dominate; the news section only displays news approved by the owner, while the audience passively receives the reported impressions. The media must survive, and to do so, sometimes the media must compromise with the resources that support them (Allern, 2002). Certain media do not present events that negatively impact their economic resources. Advertisers sometimes have their own strategies for imposing media content to their liking. Customers in many ways also influence media coverage. Certain themes are interesting and, if proven to boost sales, will be covered constantly by the media. The media will not waste the momentum of events favored by audiences.

According to Beam (2003), when the media are dominated by the power of capital owners, the information they convey becomes an instrument of interest to seek the greatest advantage by way of exploiting the audience. Media owners tend to increase their capital accumulation, which tends to lead to a media conglomerate and content that contains the interests of the owner. So, in the media economy, mass media have become a means to manipulate the audience. The media is no longer a means for audiences to get the facts right and good.

\section{Code of Ethics for Journalism in Indonesia}

Journalists are people who regularly write news to be published in the mass media and presented to the public. Journalists in Indonesia, when performing their duties, must follow a code of ethics stipulated by the Press Council in 2008 as the norms that should guide their writing of the news.

In view of this, a journalistic ethics code is a moral reference to regulate the actions of journalists (Deuze, 2005; Ibrahim, 2003; Iggers, 2018; Ryan, 2001; Starck, 2001; Sirikit, 2011; Ward, 2005). This is true in Indonesia and elsewhere; the code of ethics is a set of professional ethics that is the basis of work and behavior for journalists in Indonesia. To ensure the independence of the media and fulfill the right of the public to obtain correct information, Indonesian journalists need the moral and ethical basis of journalism as an operational guideline to maintain their integrity and professionalism. Therefore, Indonesian journalists must obey the journalistic code of ethics. Journalists should always remember that the results of their work will be read by the public and can have a very strong influence on people's lives (Arief, 2008; Sirikit, 2011).

Although the code of ethics is a guide for journalists in carrying out their profession, studies have found that journalists often violate their existing ethics (Hafez, 2002; Ibrahim, 2003). Among the issues in the code of ethics most often violated by journalists are receiving envelopes (bribes); off the record; failing to cover both sides; not maintaining the privacy rights of sources; covering obscene or sadistic news; mixing facts and opinions; and covering sex news such as cases of rape, adultery, sexual harassment, adultery, cheating, and sordid topics (Iggers, 2018; Kaplan, 2006; Sirikit, 2011; Wilkins \& Brennen, 2004). 
In fact, in the reporting of the case Indonesian journalists can apply the Journalistic Code of Ethics established by the Press Council $06 / 2008$, namely articles 3,4 and 5 . As the focus of this research, following are descriptions of articles 3 and 4 of the journalistic code of ethics in Indonesia.

Article 3 states that Indonesian journalists should always test their information, cover both sides, refrain from mixing facts and judgmental opinions, and apply the principle of presumption of innocence. Testing information means checking and rechecking the truth of the information, while covering both sides means to give space or time to the reporting of each side proportionally. Judgmental opinions are the personal opinions of a journalist. This is different from an interpretive opinion, namely the journalist's interpretation of the facts. The principle of the presumption of innocence is the principle of not judging a person.

Article 4 states that Indonesian journalists should not publish articles that are false, slanderous, sadistic or indecent (obscene) and will not identify the victim of a moral crime. Lying means presenting something that journalists know is incompatible with the facts. Slander is a baseless allegation committed deliberately with bad intentions. Sadistic work means being cruel and without compassion. Obscene means a depiction of erotic behavior with photographs, images, sounds, graphics, or writing solely for arousing lust.

\section{Material and Methodology}

This study is a quantitative research project with a content analysis approach. It examines the categories of sex news contained in the Harian Rakyat Aceh newspaper from January to April 2016. Those categories are: (1) Rape - a criminal offense that occurs when a person (or more) forces another person to have sexual intercourse; (2) Adultery - the act of intercourse between men and women done based on liking each other but without being bound by marriage; (3) Sexual harassment - the act of sexual nuance performed through physical or non-physical contact, targeting the sexual body parts of others; (4) Cheating - dishonest acts or activities that deviate from one's partner, whether boyfriend, girlfriend, husband, or wife. This term is generally used to indicate something that violates the agreement of the loyalty of the relationship between a husband and wife; (5) Sordid topics - two-sided activities between non-mahram men and women in a place of solitude that would invite adultery.
These aspects can be measured first by the frequency of their coverage in the Harian Rakyat Aceh newspaper. Second, the researcher can look at the use of proximity elements. Third, the researcher can look at the implementation of the journalistic code of ethics, focusing on three indicators: not mixing facts and opinions, not presenting sadistic stories, and not presenting obscene news. Following is a further explanation of these three indicators of the implementation of the journalistic code of ethics:

Not mixing facts and opinions--When writing, journalists must be sure that their own opinion is not added to the news. News should be delivered in accordance with the facts and not embellished with language that implies an opinion. In other words, journalists should avoid the use of words and phrases such as depraved man, crushed, naked, and anchored on a woman's body. According to Holland (2002), news is presented objectively when delivered in accordance with the facts without any element of drama and eroticism.

Not reporting sadistic news-Sadistic news is information that is cruel and does not recognize mercy. Journalists should ensure that when they convey information, for example, in relation to a rape or incident of sexual harassment, that the story is conveyed clearly but not in detail and not dramatized through the use of words and phrases such as beaten, taken hostage, tear of the vagina, etc. Such reporting is traumatic for the victim and provides a negative lesson for the reader.

Not making obscene news-Journalists should be sure that photographs, pictures, sounds, graphics, or stories about sex are described politely. That is, sex news such as rape, adultery, sexual harassment, infidelity, and the like are not conveyed with eroticism that arouses the audience's passion. For example, they should not use words such as groped, kissed, elegance, or stroked.

\section{Unit of Analysis}

News stories analyzed in this research exemplify one or more of the five categories of sex news that appeared in the Harian Rakyat Aceh newspaper during January-April 2016. This research focuses on news of rape, adultery, sexual harassment, cheating, and sordid topics. There were 54 news articles analyzed in this study.

\section{Test Reliability}

Researchers measured test reliability by using one coder as a benchmark or judge to compare coding categorization and to see the level of understanding of the category between the 
researcher and the coder. A reliability test helps ensure the objectivity of research results in a content analysis (Holsti, 1969; Kolbe \& Burnett, 1991; Krippendorff, 2004; Shah, 1990; Stemler, 2001). A coding sheet was developed to facilitate the reliability test (see Appendix). In this research, the Holsti formula was used to test the reliability of the coding: $\mathrm{CR}=2 \mathrm{M} / \mathrm{N} 1+\mathrm{N} 2$

Where $\mathrm{CR}$ is the coefficient reliability, $\mathrm{M}$ is the number of coding decisions on which the judge and the researcher agree, and N1 and N2 are the number of coding decisions made by the judge and researcher, respectively.

The higher the value obtained, the higher the reliability value (Lombard et al. 2002; Neuendorf, 2016; Riffe, Lacy, \& Fico, 2014; Riffe \& Freitag, 1997). In the Holsti formula, the minimum value is 0.75 . That is, if the calculation shows a reliability rate greater than 0.75 , the coding shows high reliability. Eleven stories $(20 \%)$ were included in the reliability test for this study. The samples were randomly selected and coding sheets were completed. Analysis showed a CR of 0.99 , indicating strong reliability.

Following the reliability test, all 54 news articles from the Harian Rakyat Aceh newspaper were analyzed using the coding sheets and SPSS software.

\section{Result and Discussion \\ Research Question 1}

Research question 1 focused on the frequency of news reports relating to sex in the Harian Rakyat Aceh newspaper. The more frequently these stories were reported, the more important the news was considered for the newspaper. Table 1 presents the results related to frequency. In March, the paper had the highest percentage of stories related to sex during the months studied. January and April had the next highest, while February had the fewest. There were sex-related stories almost every day in the paper, indicating that the news value of sex was an important issue for the Harian Rakyat Aceh.

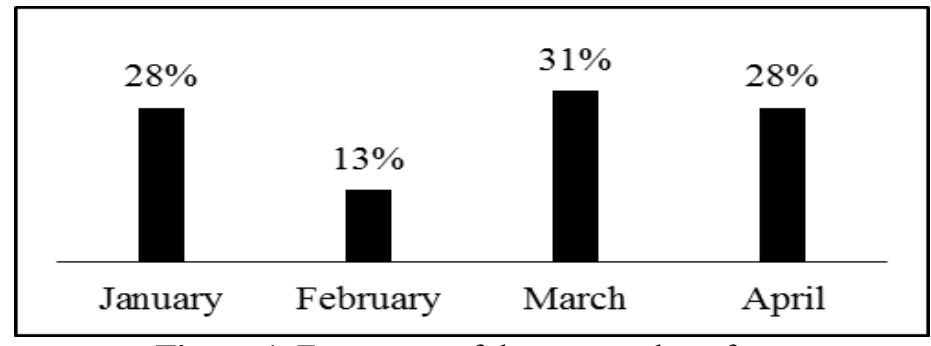

Figure 1. Frequency of the news value of sex Source: Analysis SPSS

This research question also focused on the category in which these stories lay: rape, adultery, sexual harassment, cheating, or sordid topics. Here, the aim was to see what kind of news concerning sex often appeared in the newspaper.
Figure 2 shows that stories about rape and sexual harassment were the highest reported, followed by stories of adultery and sordid topics. The fewest stories were those about cheating.

\section{Research Question 2}

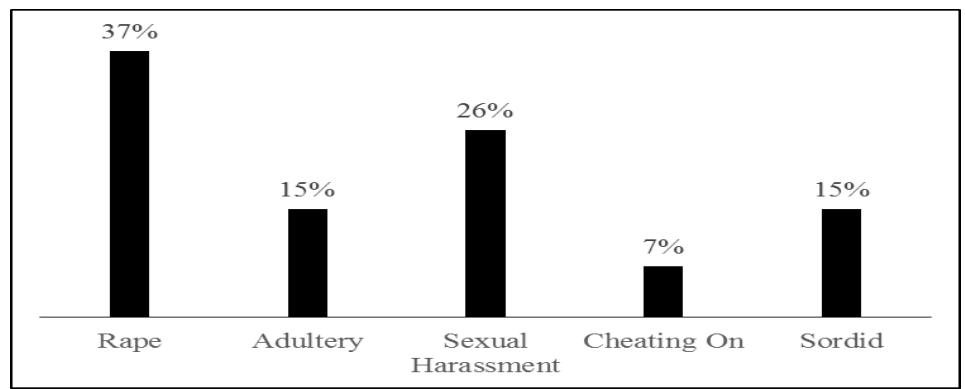

Figure 2. Type of news value of sex Source: Analysis SPSS
Proximity is the most important element in news. Something close to the audience opens a great opportunity for people to read about it. In this case, the newspaper offered its readers, the people of Aceh, stories of events close to home, ensuring high readership. Likewise, when journalists preach the value of sex news locally, of course, many people in Aceh will read it.

In figure 3 the analysis showed that there were 67 percentage stories regarding sex that had 
elements of closeness with the people of Aceh in the period January-April 2016 in the Harian Rakyat Aceh newspaper. This means that the newspaper still reported a large percentage of sexrelated stories although they had no element of closeness with the people of Aceh.

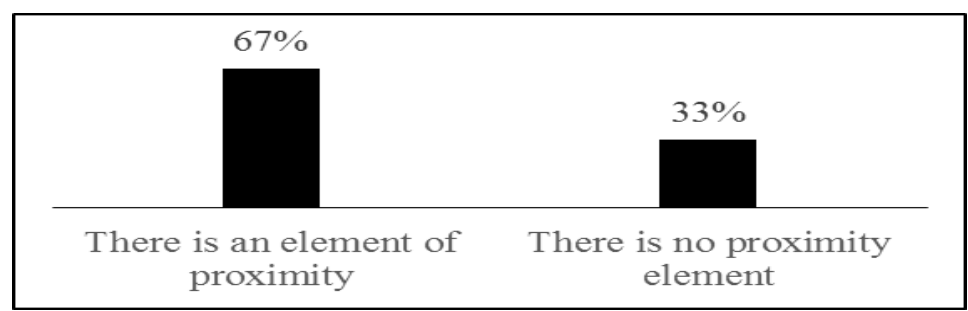

Figure 3. Category of proximity news with Aceh people Source: Analysis SPSS

\section{Research Question 3}

This research question focused on the implementation of three aspects of the code of ethics for journalists: not mixing facts and journalists' opinions, not presenting sadistic stories, and not reporting obscene stories.

Based on figure 4 , the analysis shows that more than half of the coverage of sex-related news stories failed to implement the prohibition of mixing facts and journalists' opinions. Reporters for this newspaper embellished their stories with words and phrases such as those noted previously that implied an opinion concerning the event. This indicates that the newspaper is not strict about enforcing the journalistic code of ethics.

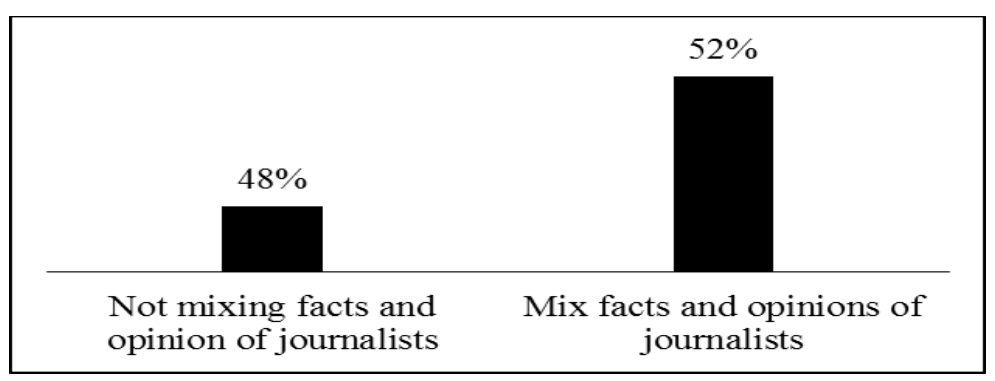

Figure 4. Not mixing facts and opinions Source: Analysis SPSS

Based on figure 5, the analysis shows that the percentage of stories that fit in the sadistic category of news coverage was 20 percentage. Although that figure is much lower than the percentage of stories that are observed in the journalistic code of ethics, it still shows a lack of strict enforcement of the code. The placement of sadistic elements is often done in news reports of rape and sexual harassment.

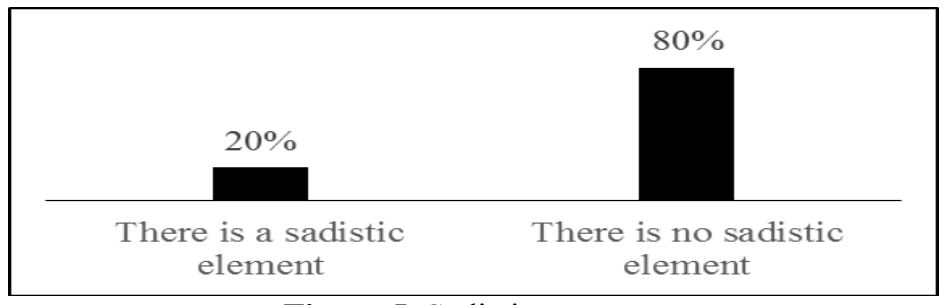

Figure 5. Sadistic category

Source: Analysis SPSS

Again, based on figure 6 the analysis shows that the newspaper failed to fully implement the journalistic code of ethics as it relates to news coverage. More than three-quarters of the stories analyzed had obscene elements, using erotic words or phrases that could arouse the lust of readers. 


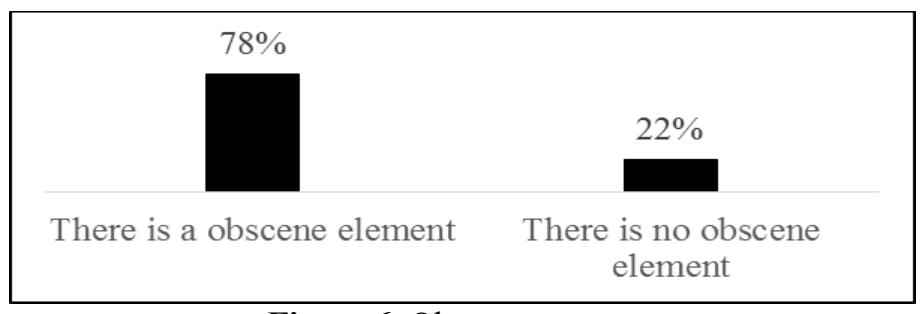

Figure 6. Obscene category Source: Analysis SPSS

The results of this research show that the Harian Rakyat Aceh newspaper has an economic interest in reporting sex-related news. As much as $33 \%$ of the sex-related news reported in the paper had no element of proximity, which is an important element in mass media coverage (DeLung et al., 2012; Shoemaker et al., 2007). The audience reads news that happens close to it and wants to know if any family or neighbor is involved with the event. The economic interests of the media can be seen again when journalists mix facts and opinions is as much as $52 \%$ of the sex-related stories, and journalists included obscene and sadistic elements in $78 \%$ and $20 \%$ of the stories, respectively.

Most media coverage moves are based on a profit-driven, economic push (Allern, 2002; Curtin, 1999; Mehra, 1988), which encourages journalists to pack the news with stories designed to attract audiences so the media can earn higher profits. According to Allern (2002), the main attraction of these stories for the audience is sensational and negative news.

The media practice the assessment and selection of news stories based on actual size, proximity, controversy and oddities (Brighton \& Foy, 2007; Galtung \& Ruge, 1965; Greer, 2010; O'Neill \& Harcup, 2009). Media reviewers often say that journalists face a dilemma in choosing between news value and the implementation of the journalistic ethics code. For example, news of a rape victim depicted with a torn vagina and a naked body would have high news value but it has ethical implications if it is broadcast. This situation often is called "news value versus bad taste." If described in graphic terms, the story would invite anger among the victim's family and provide sensationalism that would have a bad impact on the reader.

The results of this research, however, show that, when reporting news in five categories related to sex, the Harian Rakyat Aceh newspaper has no sense of responsibility toward the prevailing journalistic code of ethics that forbids journalists to write news that mixes facts with opinions or to present sadistic and obscene events. The issue of journalistic ethics is relative and often difficult to apply (Arief, 2008; Iggers, 2018; Kaplan, 2006; Sirikit, 2011; Ward, 2005; Wulfemeyer, 1985). Often media practitioners make missteps and do something contrary to journalistic ethics, especially with news relating to a sexual nature.

Mass media has a powerful function and can influence audiences either negatively or positively. Media organizations and practitioners should follow the various regulations set by the government, such as the implementation of a code of ethics, so that they do not sidestep their function, which is to convey responsible information to the audience. Iggers (2018) said the use of ethics for journalists is a guideline of behavior so that the news does not harm sources, actors, or readers. According to Ward (2005), obedience to the code of ethics can be used as a benchmark regarding the responsibilities of journalists for what is reported.

In the Press Act 1999, Indonesia saw two main functions of the media. First, the media are supposed to be honest conveyors of information to the audience. Second, the media are an economic institution that needs to be used for profit. In this regard, the press in Indonesia has two important parts: readers or audiences buying newspapers for content, and advertisers who buy advertising space to promote their products to readers. The pressures from these two parts often lead to newspapers and most mass media deviating slightly from their initial role as a tool for conveying information to audiences. The results of this study support the statement that the economic factor is always an important concern for the news media (Allern, 2002; Attaway-Fink, 2005; 2006; Beam, 2003; Jenkins, 2004; Cohen, 2002; Curtin, 1999; Mehra, 1988; Shoemaker \& Reese, 1996. This economic factor can influence the behavior of mass media owners and lead to journalists writing stories to attract readers so that the aspects of quality news and the bad impacts generated from the news will be less of a concern.

\section{Conclusions}

The results of this content analysis show that almost every day journalists of the Harian 
Rakyat Aceh reported stories having to do with sex in some way. The element of proximity with the reader was not a priority but the news value of sex is based to a great deal on the media's economic interests. Packaging the news to appeal to readers will always be a focus for the media, leading reporters to violate the journalistic code of ethics. This can be seen from the coverage of sexrelated stories in the Harian Rakyat Aceh newspaper. The paper's journalists mixed facts and personal opinions, and they included elements of an obscene or sadistic nature. The Harian Rakyat Aceh newspaper is only one media outlet, and, many others also consider important economic factors in writing the news.

The media will always think twice in news writing if the stories have economic implications for them (Allern, 2002; Attaway-Fink, 2005; Reese, 2001). Journalists in Indonesia and globally know that their writing can shape and influence the minds of audiences. Because of this, journalists should realize that they must obey journalistic ethics carefully and responsibly. Those who violate should be excluded or subject to disciplinary action.

In some media organizations in Indonesia, however, violations of the journalistic code of ethics by media practitioners often are not followed by legal witnesses. This is due to several factors, such as unclear actions/sanctions for violating journalistic ethics, irresponsible media freedom, and the existence of the Press Council as an institution granted authority by the state of Indonesia to establish and supervise the journalistic code of ethics. The Press Council has limited personnel and its central existence in Jakarta means that some media are located far from them but remain in their control. Although society in Indonesia is expected to oversee the implementation of a journalistic code of ethics, the people do not know enough about the media or to whom they should report violations.

Many researchers have said that although the journalistic code of ethics was introduced long ago, some journalists do not know about it yet (Allern, 2002; Arief, 2008; Deuze, 2005; Hafez, 2002; Iggers, 2018; Sirikit, 2011; Ward, 2005; Wilkins \& Brennen, 2004). Its application to each media is still a little loose and sometimes some media do not require journalists to know and remember the journalistic code of ethics. But because most media professionals in daily news briefings are senior journalists such as the editorin-chief, secretary, managing editor, deputy managing director, and section chairs (e.g., for politics, crime, economics, religion, socio-cultural events, sports), the ethical aspect of journalism is emphasized less. The things that often are emphasized, however, are the news headlines, stories that need to be followed up on, and news that was not covered (or missed) the previous day. But knowledge of ethics is also not conveyed strongly, let alone discussed it in depth.

Due to a lack of concern for journalistic ethics, many areas of duty and scope of journalists are not known clearly. This lack of clarity also makes journalists less memorable in carrying out their responsibilities. Some state that knowledge of journalistic ethics tends to determine and promote right and appropriate deeds (Ryan, 2001; Schmidt \& Posner, 1982; Ward, 2005). So, applying journalistic ethics in reporting implies that media practitioners are responsible, disciplined, and have high credibility as providers and spread good and positive information to the audience.

\section{References}

Allern, S. (2002). Journalistic and commercial news values. Nordicom Review, 23(1-2), 137-152. doi:10.1515/nor-2017-0327.

Arief, P. (2008). Apa itu kode etik jurnalistik. Retrieved September, 23, 2019, from http://arief-permadi.blogspot.com/2008/ 10/apa-itu-kode-etik-jurnalistik.html.

Arifin, A. (2017). Pelanggaran kode etik jurnalistik pada pemberitaan kekerasan seksual terhadap perempuan di media massa cetak: Analisis isi surat kabar "Lampu Hijau". Jurnal Kriminologi Indonesia, 10(1), 1-8. Retrieved September, 23, 2019 from http://journal.

ui.ac.id/index.php/jki/article/view/7512.

Attaway-Fink, B. (2005). Market-driven journalism: Creating special sections to meet reader interests. Journal of Communication Management, 9(2), 145-154. doi:10.1108/ 13632540510621335.

Barton, A. (2017). It's the same old story: Rape representation in New Zealand newspapers (1975-2015) (Master's thesis, Victoria University of Wellington, New Zealand). Retrieved August, 15, 2019, from http://researcharchive.vuw.ac. nz/handle/10063/ 6593.

Baum, M. A. (2002). Sex, lies, and war: how soft news brings foreign policy to the inattentive public. American Political Science Review, 96(1), 91-109. S0003055402004 252.

doi:10.1017/

Beam, R. A. (2003). Content differences between daily newspaper with strong and weak market orientations. Journalism \& Mass 
Communication Quarterly, 80(20), 368-390. doi:10.1177/107769900308000 209.

Blood, D. J., \& Phillips, P. C. (1997). Economic headline news on the agenda: New approaches to understanding causes and effects. In M. E. McCombs, D. L. Shaw, \& D. H. (Eds.), Communication and Democracy: Exploring the Intellectual Frontiers in Agenda-Setting Theory (pp. 97113). Mahwah, NJ: Lawrence Erlbaum Associates.

Cohen, E. L. (2002). Online journalism as marketdriven journalism. Journal of Broadcasting Electronic Media, 46(4), 532-548. doi:10.1207/s15506878jobem4 6043.

Curtin, P. A. (1999). Reevaluating public relations information subsidies: Market-driven journalism and agenda-building theory and practice. Journal of Public Relations Research, 11(1), 53-90. doi:10.1207/s1532754xjprr1101_03.

DeLung, J., Magee, R. G, DeLauder, R., \& Maiorescu, R. (2012). Proximity and framing in news media: Effects on credibility, bias, recall, and reader intentions. Journalism Communication, 2(7), 748-757.

Deuze, M. (2005). What is journalism? Professional identity and ideology of journalists reconsidered. Journalism, 6(4), 442-464. doi:10.1177/146488490 5056815.

Dimmick, J., \& Rothenbuhler, E. (1984). The theory of the niche: Quantifying competition among media industries. Journal of Communication, $\quad 34(1), \quad$ 103-119. doi:10.1111/j.1460-2466.1984.tb02 988.x.

Elliott, D. (1988). All is not relative: Essential shared values and the press. Journal of Mass Media Ethics, 3(1), 28-32. doi:10.1080/ 08900528809358306.

Fengler, S., \& Rub-Mohl, S. (2008). Journalist and the information attention markets: Towards and economic theory of journalism. Journalism: Theory, Practice \& Criticism, $9(6), \quad 667-690$. doi:10.1177/ 146488 4908096240.

Fuller, J. (1996). News values: Ideas for an information age. Chicago, IL: University of Chicago Press.

Galtung, J., \& Ruge, M. H. (1965). The structure of foreign news. Journal of Peace Research, 2(1), 64-91. doi:10. $1177 / 002234336500200104$.

Greer, C. (2010). News media criminology. In E. McLaughlin \& T. Newburn (Eds.), The SAGE handbook of criminological theory (pp. 490-513). Thousand Oaks, CA: Sage Publications Ltd.
Hafez, K. (2002). Journalism ethics revisited: A comparison of ethics codes in Europe, North Africa, the Middle East, and Muslim Asia. Political Communication, 19(2), 225-250. doi:10.1080/10584600 252907461.

Harcup, T., \& O'Neill, D. (2001). What is news? Galtung and Ruge revisited. Journalism Studies, 2(2), 261-280. doi:10.1080/14616700118449.

Harcup, T., \& O'Neill, D. (2017). What is news? News values revisited (again). Journalism Studies, 18(12), 1470-1488. doi:10.1080/ 1461670X.2016.1150193.

Harris, R. J., \& Scott, C. L. (2002). Effects of sex in the media. In J. Bryant \& M. B. Oliver (Eds.) Media Effects: Advances in Theory and Research (2nd ed., pp. 307-331). Mahwah, NJ: Lawrence Erlbaum Associates.

Holland, P. (2002). The politics of the smile: 'Soft news' and the sexualisation of the popular press. In C. Carter, G. Branston, \& S. Allen (Eds.), News, gender and power (pp. 29-44). New York, NY: Routledge.

Holsti, O. R. (1969). Content analysis for the social sciences and humanities. Reading, MA: Addison-Wesley.

Ibrahim, F. (2003). Falsafah dan etika kewartawanan di Malaysia: Antara tuntutan profesionalisme dan kepentingan industri. Jurnal Komunikasi, 19(1), 59-78.

Iggers, J. (2018). Good news, bad news: Journalism ethics and public interest. New York, NY: Routledge.

Jenkins, H. (2004). The cultural logic of media convergence. International Journal of Cultural Studies, 7(1). 33-43. https://doi.org/10.1177/1367877904040603.

Kaplan, R. L. (2006). The news about new institutionalism: Journalism ethic of objectivity and its political origins. Political Communication, 23(2), 173-185. doi:10.1080/10584600600629737.

Kitzinger, J. (2004). Framing abuse: Media influence and public understanding of sexual violence against children. London: Pluto Press.

Kolbe, R. H., \& Burnett, M. S. (1991). Contentanalysis research: An examination of applications with directives for improving research reliability and objectivity. Journal of Consumer Research, 18(2), 243-250. doi:10.1086/209256.

Krippendorff, K. (2004). Reliability in content analysis. Human Communication Research, 30(3), 411-433. doi:10.1111/ j.1468958.2004. tb00738.x. 
Lee, J. H. (2009). News values, media coverage, and audience attention: An analysis of direct and mediated causal relationships. Journalism \& Mass Communication Quarterly, 86(1), 175-190. doi:10.1177/107769900908600111.

Lombard, M., Snyder-Duch, J., \& Bracken, C. C. (2002). Content analysis in mass communication: Assessment and reporting of intercoder reliability. Human Communication Research, 28(4), 587-604. doi:10.1111/j.1468-2958.2002.tb00 826.x.

Malik, A. (2018). Jurnalisme kuning 'lampu kuning' etika komunikasi massa. Jurnal Ajudikasi, 1(2), 1-14. http://dx.doi.org/ 10.30656/ajudikasi.v1 i2.492.

McManus, J. (1995). A market-based model of news production. Communication Theory, 5(4), 301-338. doi:10.1111/j.1468885. 1995.tb00113.x.

Mehra, A. (1988). Newspaper management in the news multimedia age. Singapore: AMIC.

Mosco, V. (1996). The political economy of communication. London, UK: Sage.

Neuendorf, K. A. (2016). The content analysis guidebook. Thousand Oaks, CA: Sage.

O'Neill, D., \& Harcup, T. (2009). News values and selectivity. In K. W. Jorgensen \& $\mathrm{T}$. Hanitzsch (Eds.), The Handbook of Journalism Studies (pp. 161-174). New York, NY: Routledge.

Otto, H. A. (1963). Sex and violence on the American newsstand. Journalism Quarterly, 40(1), 19-26. doi:10.1177/107 769906304000103.

Picard, R. G. (2010). The future of the news industry. In J. Curran (Ed.) Media and society (pp. 365-379). London, UK: Bloomsbury Academic.

Reese, S. D. (2001). Understanding the global journalist: A hierarchy of influences approach. Journalism Studies, 2(2), 173-187. doi:10.1080/14616700118394.

Riffe, D., Lacy, S., \& Fico, F. (2014). Analysis media messages: Using quantitative content analysis in research. New York, NY: Routledge.

Riffe, D. \& Freitag, A. (1997). A content analysis of content analyses: Twenty-five years of Journalism Quarterly. Journalism \& Mass Communication Quarterly, 74(3), 515-524. doi:10.1177/107769909707400 306.

Russ-Mohl, S. (2006). The economics of journalism and the challenge to improve journalism quality. A research manifesto. Studies in Communication Sciences, 6(2), 189-208.
Ryan, M. (2001). Journalistic ethics, objectivity, existential journalism, standpoint epistemology, and public journalism. Journal of Mass Media Ethics, 16(1), 3-22. doi:10.1207/S1532 7728JMME1601_2.

Ryan, M. \& Tankard, J. W. (1977). Basic news reporting. New York, NY: Mayfield Publishing Co.

Schmidt, W. H., \& Posner, B. Z. (1982). Value: The silent power. In W. H. Schmidt \& B. Z. Posner (Eds.), Managerial values and expectations: The silent power in personal and organizational life (pp. 12-16). New York, NY: AMA.

Setiowati, E. (2010). Infotainment: Kebebasan atau keblablasan ditinjau dari kajian ekonomi politik media. Humaniora, 1(1), 20-28.

Shah, H. (1990). Some methodological considerations for the study of development news: An examination of three Indian daily newspapers. International Communication Gazette, 45(1), 33-48. doi:10.1177/001654929004500104.

Shoemaker, P. J., Lee, J. H., Han, G., \& Cohen, A. A. (2007). Proximity and scope as news values. In E. Devereux (Ed.) Media Studies: Key Issues and Debates (pp. 231-248). London, UK: SAGE.

Shoemaker, P. J., \& Reese, S. D. (1996). Mediating the message: Theories of influences on mass media content. London, UK: Longman.

Singer, J. B. (2010). Quality control: Perceived effects of user-generated content on newsroom norms, values and routines. Journalism Practice, 4(2), 127-142. doi:10.1080/17512780903391979.

Sirikit, S. (2011). Rambu-rambu jurnalistik dari undang-undang hingga hati nurani. Yogyakarta: Pustaka Pelajar.

Starck, K. (2001). What's right/wrong with journalism ethics research? Journalism Studies, 2(1), 133-152. doi:10.1080/ 14616700119246.

Stemler, S. (2001). An overview of content analysis. Practical Assessment, Research \& Evaluation, 7(17), 137-146.

Sultana, W., \& Harikrishnan, B. (2014). Portrayal of violence against women: A content analysis of Manipal rape reportage in three leading English Dailies of Karnataka. Human Rights International Research Journal, 2(1), 413-417.

Susilastuti, D. N. (2000). Kebebasan pers pasca orde baru. Jurnal Ilmu Sosial dan Ilmu Politik, 4(2), 221-242. 
Van Zoonen, L. (1988). Rethinking women and the news. European Journal of Communication, 3(1), 35-53. doi:10.11 77/026732318800300 1003.

Ward, S. J. (2005). Philosophical foundation for global journalism ethics. Journal of Mass Media Ethics, 20(1), 3-21. doi:10.1207/s15327728jmme2001_2.
Wilkins, L., \& Brennen, B. (2004). Conflicted interest, contested terrain: Journalism ethics codes and now. Journalism Studies, 5(3), 297-309. doi:10.1080/146167004 2000246061.

Wulfemeyer, K. T. (1985). Ethics in sports journalism: Tightening up the code. Journal of Mass Media Ethics, 1(1), 57-67. doi:10.1080/08900528509358256. 